\title{
Prospects for the development of direct seed planting technology (Tabela) in Indonesia
}

\author{
Sahardi", Abdul Wahid Rauf, M. Basir Nappu, Idaryani, Kartika Fauziah, Nurlaila, Repelita \\ Kallo, and Amiruddin Syam \\ Assessment Institute for Agricultural Technology (AIAT) South Sulawesi, Jl. Perintis Kemerdekaan \\ KM 17,5, Makassar, Indonesia
}

\begin{abstract}
Prospect for the development of direct seed planting technology (Tabela) in Indonesia. This paper is a review that aims to reveal the development of technological innovations for direct seed rice cultivation (Tabela) and the prospects for its development in Indonesia. Rice is the main source of food, which cannot be substituted with other foodstuffs. The need for rice will continue to increase, along with the rate of increase in population growth every year. Therefore, the main program for agricultural development in periods 2015-2019 is to increase productivity and cropping indexes in all rice agro-ecosystems. The main problems in the current rice cultivation business today are; the need for labor is large, while the availability of labor in the agricultural sector is decreasing, farm labor wages and the price of production facilities are getting more expensive, the area of rice fields is decreasing, the availability of water is increasingly limited. Direct seed cultivation of jajar legowo is one of the solutions for lowland rice farming that can solve the problem of labor shortages in the production process of rice cultivation. Supporting technology in Tabela rice cultivation is quite available including superior varieties, seed technology, biological fertilizers, fertilization, weed control, water management, pest and disease control, and planting tools. Tabela technology has the prospect to be widely developed in Indonesia because it is suitable for irrigated and rain fed rice fields, harvest faster, increases production, is more labor efficient, easy and practical to implement.
\end{abstract}

\section{Introduction}

Rice is the main source of food especially in Indonesian people. The presence of rice cannot be substituted with other foodstuffs. The need of rice will continue to increase, in line with the rate of increasing population growth each year. Therefore, the main program of agricultural development aims to increase productivity and crop indexes in all rice agroecosystems. The availability of adequate irrigation water, cheap herbicides, early age rice varieties, and increasingly expensive labor wages have encouraged farmers in Malaysia, Philippines and Thailand to switch from planting rice using the tandur jajar system to direct spread cultivation [1]. In Indonesia, the methods of planting only widely developed since 1995 which began with the SUTPA Study in 14 Provinces in Indonesia.

* Corresponding author: muliasahardi@gmail.com 
The technologies developed in SUTPA include: (1) direct seed planting systems (Tabela) and (2) introduction of agricultural machine tools (alsintan) including: direct seed planting tools (Atabela). Lowland rice cultivation using the Tabela system is methods of the planting rice plants without going through the nursery and transferring the seeds. This technology makes the rice planting life is shorter. The use of tools in the form of Atabela is an important factor in efforts to increase the efficiency of farming. The use of alsintan playing important role in overcoming labor shortages due to developments in the industrial sector. The method of cultivating the land in the Tabela system of rice cultivation has the same principle of transplanted rice cultivation. In increasing the optimal results, the perfect soil cultivation still required. The deep tillage will make easier for the roots to enter deeper into the soil and makes the rice plant does not fall easily. The surface is flat support water level can easier controlled [2].

The need for labor in large numbers is a problem in the rice cultivation business, because current the availability of labor in the agricultural sector is decreasing, farm labor wages and production facilities are increasingly expensive, when the area of rice fields is decreasing and water availability is increasingly limited [3]. The innovation of super direct seed planting rice cultivation (Super Tabela) is one of the solutions to overcome the problems described previously. Super Tabela is a method of planting rice without going through a nursery and transferring seeds. The rice seeds are directly sown on fields that have been properly processed and supported by the application of modern agricultural technology: new superior varieties with high yield potential, balanced fertilization, biological fertilizers (seed treatment), bio-decomposer and integrated pest control. This factor support adaptability of the seedling of the Tabela system is better and the initial root growth faster.

Super Tabela has various advantages among others technology such as: easy and practical to implement, labor-saving, cost-effective, efficient in water use, faster harvesting, interesting to farmers and higher production compared to traditional planting methods (Tapin). Tabela technology innovation has developed widely in several areas, including: South Sulawesi, West Sulawesi, Southeast Sulawesi, Central Sulawesi, North Sulawesi, West Nusa Tenggara, East Nusa Tenggara, Central Kalimantan, East Kalimantan, South Sumatra, Riau and Jambi [4]. This paper is a review that aims to reveal the development of technological innovations in direct seed rice cultivation (Tabela), and the prospects for its development in Indonesia

\section{The development of rice cultivation technology innovation of direct seed planting (Tabela)}

Although the direct seed planting rice cultivation technology (Tabela) has never been recommended, Tabela cultivation technology has developed rapidly, in line with the increasing lack of labor in the agricultural sector. The rapid development of Tabela technology because Tabela is not only suitable for irrigated rice fields and suitable in rainfed rice fields, tidal fields and lowland swamps [5,6]. Its implementation is practical, easy and cheap for farmers. Tabela has developed into four planting methods, namely: (1) Tabela evenly distributed (broadcast); (2) Tabela forming tiles/tegelan; (3) Tabela in rows/Tabela larikan; (4) Tabela jajar legowo super [4,7]

\subsection{Tabela in evenly distribution (broadcast)}

Tabela system with evenly distribution or broad cast is method of planting rice by sowing seeds on rice fields that have been properly cultivated. Based on the results of the study [5], 
it is known that the beginning of Tabela rice cultivation in rice fields in South Sulawesi around 1975, with the Tabela system of even distribution (broad cast), the number of seeds used is up to $100 \mathrm{~kg} /$ hectare, but the production is lower. The advantage of Tabela in evenly distributed is very practical, easy, cheap with a very fast planting time of 2 hours/hectare/ person on average, with a planting cost around Rp. 120.000-150.000/hectare [8]. Also, Tabela in evenly distributed has the most cost and energy efficient [9].

The weaknesses of the method commonly use a lot of seeds, the plant population is very dense, the plants growth irregular, easy attacking by rats, birds and golden snails, fast weed growth, difficult in maintenance (fertilization, weeds management, pest and disease control), short panicles, small grain with a lot of weed mix, as a result of low productivity and quality results [10-11]. The prospect of development, Tabela in evenly distributed has the opportunity to be developed with a record of reducing the number of seeds, which is around $25-35 \mathrm{~kg} / \mathrm{hectare}$ and setting the space for maintenance such as: fertilization, pest, disease and weed control [12].

\subsection{Tabela forming tiles (Tabela tegel)}

The system of Tabela tegel (Tabela forming tiles) is an improvement from Tabela evenly distributed technology. Tabela tiles method is a tile-shaped Tabela (tandur jajar system). Commonly, this technology in forming tiles (four squares) and the seeds placed at the point of intersection from the two lines. This system makes the planting area looks more regular and neat. Tabela tiles technology as the solution to the problem of Tabela evenly distributed, such as the number of seeds is more efficient $(60-70 \mathrm{~kg} / \mathrm{hectare})$, the plants more organized and tidy, the maintenance of plants is easier and the results are equivalent to transplanting [13]. Especially farmers in South Sulawesi mentioned Tabela forming tiles as Tabela jappo' or Guguk [10].

The advantages of Tabela forming tiles system are regular, tidy plants, easier plant maintenance, faster harvesting age, free of weeds mix grain, high productivity and equivalent to transplanting. The weakness of Tabela tiles that requires more labor and longer planting time. Presence of weeds, rats, birds and golden snails are still a problem in every season. Rice seeds growth using Tabela tiles system need intensive care at the age of 0 -10 days after planting [10]. The prospect of development is less attractive to farmers make less developed in the community.

\subsection{Tabela in rows (Tabela larikan)}

Tabela in rows or Tabela larikan is a next development of Tabela forming tiles system. The Tabela larikan as technology planting rice seeds using a direct seed planting tool (Atabela) made from paralon pipes. The implementation of the Tabela start from complete tillage and leveled. Planting seeds in the form of an array (in rows), there are spacing between rows but in rows there is no distance. The advantages of Tabela in rows more easy and practical to implement, fast planting time, saving energy for planting because need only one person for one hectare with an average planting time of 3 hours/hectare, plant maintenance is easier, weeds and golden snails can be handled, productivity is equivalent than Tapin technology. Even in some areas the yield is higher than transplanting [12].

The weakness of the use of seeds is still a lot $(50-60 \mathrm{~kg} / \mathrm{ha})$, rats and birds are still a problem. Tabela larikan still need intensive care at the beginning of growth, especially at the age of 0 - 10 days after planting. The development of this technology is very prospective and has been widely developed in the community [14]. 


\subsection{Tabela jajar legowo super (Super Tabela)}

Tabela jajar legowo super or Super Tabela is a development of Tabela larikan (Tabela in rows). Tabela jajar legowo super practice as Tabela planted using Atabela in jajar legowo system (in row). The rice plant population can regulated by applying legowo $2: 1$ or $4: 1$ [12]. The Atabela used as modified the seed groove holes with diameter 1.0 to $0.5 \mathrm{~cm}$. The technology using rice seeds more efficient $25-35 \mathrm{~kg} / \mathrm{ha}$ [15]. The supporting technology components of the Super Tabela such as: high yield potential superior varieties, water management, weed control, biological fertilizers, biodecomposers, straw compost, inorganic fertilizers as well as pest and disease control with vegetable pesticides.

One of the important advantages of the Super Tabela technology, the harvesting age is 10-15 days planting, faster than Tapin technology, which greatly supports the development of various cropping patterns. In Sulawesi, the planting pattern of rice-rice-rice (IP 300) has been developed in technically irrigated rice fields such as in Sidrap and Pinrang districts. In rainfed lowland land, the cropping pattern of rice - palawija (soybean/maize) develops, such as in Bone, Soppeng, and Wajo districts [4].

Then, another advantages of Super Tabela are: technically, easy and practical, cost effective, energy efficient, saving seeds and faster harvesting life [6]. The weeds, golden snails, rats and birds have been resolved, farming is efficient, farmers productivity and income have increased significantly. Super Tabela has overcome other Tabela superior to Tapin. The Super Tabela very adaptable and possible applied to various types of land, and the response of farmers is very positive, especially in South Sulawesi such as Bone, Wajo, Sidrap, Pinrang, Luwu, North Luwu and East Luwu districts [4].

Based social and cultural, technology of Tabela giving advantages farmers have more time spent with their families or finish another work. Therefore, Super Tabela is recommended to be developed more widely to support the realization of sustainable food self-sufficiency.

The weakness of Super Tabela super technically is: supporting materials such as biological fertilizers, biodecomposers and biopesticides are still limited in availability. In socio-cultural terms, namely in labor-intensive areas, it has an impact on reduced employment opportunities, also reduces the nature of mutual cooperation. The prospect development of Tabela is highly recommended to be developed widely.

Based on the water management system in rice fields, Tabela is known for two types such as: Tabela saturated water and Tabela stagnant water. Tabela water saturation is Tabela which is carried out on rice fields have been completely processed and leveled, in mud or water-saturated conditions [16]. The advantages of system are easy planting and maintenance, regular plants, neat and efficient use of water. Tabela's weakness in muddy land conditions such as : plants in the germination phase has the potential to be disturbed by rats, birds, and the rapid growth of weeds. However, these weaknesses can be overcome with the availability of new technology. Handling of rats and birds with water height settings in the plots, handling weeds with selective pre-grown herbicides and handling golden snails using selective molluscicides. Tabela stagnant water is Tabela technology in stagnant water conditions in rice fields. Tabela stagnant water is the development of Tabela in water-saturated land conditions. Previously, farmers only performed Tabela on watersaturated land, because they were worried that the seeds would not grow in water. Currently Tabela has been developing on waterlogged land.

The results of research at the Indonesian Center for Rice Research showed that several introduced lines from IRRI were able to germinate and grow well $(95 \%)$ in a pool of water depth about $9 \mathrm{~cm}$. Research on this line is still ongoing. The results of a rapid evaluation study to obtain a puddle tolerant variety showed that Inpari 9 and Inpari 32 varieties germinated and grew well (81-82\%) at a water depth of $7.5 \mathrm{~cm}$ (anaerobic) [6,14] 
Tabela stagnant water widely used in areas where weeds are a major problem. This system is widely used in California (United States), Australia, and Malaysia, to suppress the development of weeds that are difficult to control. Rice varieties that are suitable for these conditions are varieties that tolerant of standing. This condition, they are able to germinate and grow in anaerobic conditions [6].

The advantages of Tabela on inundated water conditions; weed growth is inhibited, plants are protected from disturbance by rats and birds. Tabela's weakness in stagnant water conditions; easy to fall down plants, superior varieties are not available and specific fertilizer formulas are suitable for stagnant water ecosystem conditions (anaerobic). Golden snail disorders can be overcome with selective molluscicides, while irritability is overcome with wet-dry irrigation technology.

\section{Supporting technology Tabela rice cultivation}

Direct seed cultivation technology (Tabela) is an integrated rice cultivation technology requires synergy of technological innovation in its implementation. In order to overcome the challenges of applying Tabela technology and increasing rice production, supporting technological innovations are needed as follows:

\subsection{Superior varieties}

Superior varieties are one of the technology components playing an important role in the success of Tabela technology [17]. The general requirements for high yielding varieties suitable for Tabela are; able to adapt well to the growing environment in Tabela, the sprouts phase grows fast, deep roots, germinates and grows well in aerobic conditions, stems are sturdy and not tall, panicles are stable and high productivity [18].

Superior varieties showed different responses to planting in Tabela. Based on the results of the study, it is known that the Lok Ulo, Gilirang and Cimelati varieties responded well to the Tabela method, with the respective production of $7.18,6.49$ and 6.45 tonnes/hectare of harvested grain dry/GKP, while the Fatmawati variety provided lower response with yields of 4.48 tonnes/hectare $[8,16]$. New superior varieties that have developed widely in South Sulawesi include Inpari 4, Inpari 7, Inpari 8, Inpari 9, Inpari 30, Inpari 32 and Inpari 33 [19] and varieties according to Tabela on waterlogged land among Inpari 9 and Inpari 32 $[14]$.

\subsection{Seed technology}

The use of quality seeds will ensure the success of rice farming. The source quality seeds are clear, the seed quality guaranteed and the genetic purity is known such as from the appropriate superior varieties. This factor will increase farmers income. The health, quality and pure seeds possible increase yields by up to $25 \%$ [20]. Unhealthy seeds condition have less than optimal vigor and germination, which can lead to a decrease in yield of up to $20 \%$ [21].

The number of seeds affects the production of direct seed cultivation. The number of seeds is $35 \mathrm{~kg} /$ hectare giving a yield of 7.82 tonness/hectare harvested grain dry, higher than $50 \mathrm{~kg} /$ hectare only 4.82 tonnes/hectare. This is due to the use of seeds of $50 \mathrm{~kg} / \mathrm{hectare}$ which caused the plant population is very dense, with an indication of the number of productive tillers, the number of grains per panicle, 1000 grain weight is lower with a higher vacuum [15]. 
In the development of a broader Tabela to optimize the productivity of the rice plant in the Tabela system, it is necessary to select specific seeds such as seeds before planting, only planting seeds that are suitable for growth.

\subsection{Biofertilizers}

Biofertilizers are non-pathogenic microbial-based fertilizers can produce phytohormones (plant growth-promoting substances), nitrogen fixing and phosphate solvents that function to increase soil fertility and health. One of the common biological fertilizers that used is Agrimeth. Biological fertilizer has enzymatic and phytohormone activity with positive effect on the absorption of macro and micro soil nutrients, promotes growth, flowering, ripening of seeds, breaking dormancy, increasing seed vigor and viability, efficient use of inorganic fertilizers such as NPK and plant productivity [7].

The dosage of Agrimeth biological fertilizer is $0.5 \mathrm{~kg} / 30 \mathrm{~kg}$ of seeds. Application of biological fertilizer only once, when the seeds will planting in Tabela (seed treatment). Seed treatment is carried out in the morning at the latest around $8.00 \mathrm{am}$ and in the afternoon at around 15.00-17.00 pm. The rice seeds must be planted no later than three hours after treatment of the seeds [7].

\subsection{Fertilization}

Several methods and tools to increase the efficiency of N, P, and K fertilizers for lowland rice are available. Fertilizer dosages are determined based on the results of soil analysis and plant needs [12]. Urea given three times, while SP-36 and $\mathrm{KCl}$ fertilizers or compound fertilizers (NPK) are given at the beginning of planting [22]. An effective basic fertilizer application innovation is to use the Tabela planting tool, this method can give an average yield 10.35 tonnes/hectare of harvested grain dry in Super Tabela jajar legowo 2: 1 [23 24]. It is recommended used specific fertilizer formula, especially Tabela in stagnant water conditions.

\subsection{Organic materials}

Organic matter is very influential in increasing crop production, including rice plant. The need for organic material is quite a lot around 5 tonnes/hectare. There are quite a lot of organic material sources, such as livestock waste, agricultural waste and legume group plants [25]. Because the large needs of organic matter, the provision of organic materials "in situ" such as rice straw in rice fields is very helpful for farmers [26]. The combination of 2 tonnes/hectare of organic and inorganic fertilizers (100 kg Urea $+200 \mathrm{~kg} \mathrm{NPK} / \mathrm{hectare}$ ) in Tabela gives a result of 8.23 tonnes/hectare [27].

\subsection{Weeds control}

Weeds are a very important problem in Tabela rice cultivation. Without control, the presence of weed can reduce yields by $20-53 \%$ [27], then complete tillage can suppress weed growth [28]. Also, the technique of stagnating water in rice fields will inhibit weed growth. Weed control methods in Tabela also use selective pre-growth and post-growth herbicides [29 - 30]. 


\subsection{Water management}

In direct seed planting technology, a water management system is very important, irrigation water needs to be managed properly, especially 0-10 days after Tabela processes. The setting of the water level is adjusted to the rate of plant growth [30]. Setting the height of the water in the rice field also suppress weed growth. The wet - dry system water management will save water usage and prevent the plant from overcrowding.

\subsection{Pest and disease control}

The pests that attack Tabela rice are the same as find in Tapin rice technology. However, at the beginning of the growth, the dominant pests in Tabela are rat (Rattus argentiventer Robb \& Kloss), sparrows (Lonchura punctulata L.) and golden snails (Pomacea canaliculata Lamarck). Rats are very important destructive pests in Tabela rice cultivation. Control should be carried out in an integrated manner with the use of poisonous bait, toxic fumes (sulfur/carbide), traps, and mechanical means with the gropyokan. Apart from rats, golden snail as pests at the beginning of plant growth need farmer attention [14]. Control of rats and birds at the beginning of the growth of Tabela rice can be done by adjusting the height of the waterlogged in rice fields according to the age of the plants [13].

The control of golden snails used regulating water in the rice fields and making channels support the fields easy to dry. Commonly control of golden snails by chemical using selective molluscicides $[9,14]$.

\subsection{Direct seed planting tool}

The use of direct seed planting tools (Atabela) in Tabela technology is very helpful for farmers in completing rice planting. The Atabela is a development of Atabela which was introduced by the Government in 1987. Atabela has been made a series of iron, very heavy to operate. Basec fact on the field, Atabela has made several changes. The initial example of Tabela uses seeds of $50-60 \mathrm{~kg} /$ hectare, and after improving the results, the use of seeds is $25-35 \mathrm{~kg} /$ hectare. Another modification that Atabela wheels were originally made of planks, changed by replacing bicycle wheels and finally the Atabela wheels were replaced with corks, making it easier to operate [4].

The manufacture of Atabela uses a 4-inch paralon pipe as the main raw material, driven by the wheel axel. The ingredients for making Atabela are quite available at affordable prices for farmers and they can produce Atabela themselves. The test results of the Atabela design used by farmers were known to be able to complete 1 hectare in 3.086 hours. Atabela is very helpful in planting Tabela rice cultivation, compared to traditional planting methods (transplanting) [31]. Harvesting equipment is also needed to increase the efficiency of Tabela technology [32]. For the future goal, farmers has planting tool uses a machine that easy to operate, practical and affordable price is expected.

\section{Tabela technology development prospects}

Several research results indicate that the application of rice farming technology to spread directly, especially in rows, has quite an encouraging prospect. Rice cultivation technology spreads directly in ecologically possible areas to reduce the use of labor and production costs as long as it is supported by varieties with high yield potential. On the other hand, the decreasing real price of rice in several producing countries and the increasingly high cost of 
weeding in the tandur jajar planting system has encouraged farmers to switch to the direct distribution system. Thus, the positive response of farmers to rice farming with the direct distribution system is a natural thing because they are trying to reduce production costs without sacrificing the productivity of the broad union.

Direct seed rice cultivation technology (Tabela) has a very bright prospect to be developed in Indonesia because conditions are not much different from neighboring countries such as Malaysia, the Philippines and Thailand, which first developed the technique of planting Tabela rice. However, this system requires a more specific variety of rice. Tabela technology has the prospect of being widely developed, because the harvest is faster, increases production, saves more labor, is easy and practical to implement. If the harvest is faster, the planting index (IP) will increase, strong related to production, the farming system is more efficient and profitable. Super Tabela technology is not only applied to irrigated rice fields, but also to rainfed, tidal and swampy fields, including 9.9 million hectares of reserve land for rice field expansion [33]. Super Tabela also has the potential to be developed on quite extensive dry land (upland rice), both in monoculture and intercropping with other crops such as plantation crops.

Various technological innovations to support the application of Super Tabela technology are also available, such as; superior varieties with high yield potential, time and proper fertilizer application method, pest/disease and weed control, number of seeds, direct seed planting tools (Atabela) have been modified increasing the use of seeds is more efficient. For the development of Super Tabela technology in the future, all of the above challenges must be overcome by conducting research. Examples of research on the assembly of new high yield potential varieties suitable for various development ecosystems of Tabela such as; irrigated rice fields, rainfed rice fields, lowland swamps and tidal fields.

The Super Tabela technology is very suitable in supporting the rice cropping index improvement program on 3.9 million hectares of rainfed lowland land has limited water resources [33-34]. While the supporting technology for the application of the Tabela system of rice cultivation is available, moreover, its implementation is very practical, easy, fast, labor-saving and low cost planting. Currently, there are 24 provinces $(70.6 \%)$ in Indonesia with less agricultural labor force [34]. This is an opportunity for the development of the application of Tabela technology.

A special program UPSUS in accelerating the achievement of food self-sufficiency, Tabela technology plays a strategic role in accelerating the added area of planting. Increasing rice production through the Jarwo Super program, in South Sulawesi in several districts such as: Bone, Wajo, Sidrap, and Luwu, Jarwo Super technology is carried out with Super Tabela technology. Super Tabela rice cultivation technology integrated with cattle, is an alternative farming system has the opportunity developing to support sustainable food self-sufficiency. Rice cultivation Tabela integration of cattle helps farmers in providing organic fertilizers, the use of chemical fertilizers more reduced. Cows playing important roles as factories that provide organic fertilizers for farmers to use on their crops. On the other hand, rice plants provide waste as a source of energy and feed for cattle.

The study of rice-cattle integration in agro-political areas in Barru and the bio-industrial agriculture program in Soppeng, South Sulawesi has succeeded in encouraging the widespread use of rice straw as cattle feed in South Sulawesi [35]. Rice-duck-fish integration also has the opportunity to support food security and increase farmers income However, currently it is difficult to develop considering the intensive use of herbicides and pesticides by farmers.

The cropping system is an optimal land use approach to increase farmers production and income. Tabela technology can encourage an increase in the cropping index in various rice agro-ecosystems. For example, in irrigated rice fields, a cropping pattern is likely to be developed: rice-rice-rice (IP. 300) such as in Sidrap and Pinrang districts, rainfed lowland 
land with a cropping pattern: rice-secondary crops (palawija). If rainfall is sufficient, the cropping pattern: rice- rice-secondary crops (palawija) such as in Bone, Soppeng and Wajo districts. For dry land, various alternative cropping patterns that can be developed include: cropping patterns for food crops (field rice-maize or peanuts or green beans). The cropping pattern of food crops (field rice-soybean) integrated with plantation crops [23]. The cropping pattern for field rice-soybean or green beans. The cropping pattern needs technology support. Examples of Tabela technology for accelerated planting, fertilization technology and utilization of fertilizer residues. The cropping pattern is more efficient with the use of $\mathrm{P}$ fertilizers because the second crop can utilize the P residue from the first crop [29].

Based on the previous discussion, the goals and strategies for developing the technology of rice cultivation in the Tabela system can explained as follows:

\subsection{Development goals}

The targets for the development of Super Tabela technology are: (1) Super Tabela or Tabela jajar legowo super, as one of the technology options for rice cultivation; (2) increased production and productivity of rice plants; (3) creating efficient rice farming; (4) increase in farmers income; (5) realizing food self-sufficiency and (6) as a means of strengthening sustainable food self-sufficiency.

\subsection{Development strategy}

The technology development strategy for the Tabela rice cultivation can be applied includes: (1) application of the Super Tabela technology: in irrigated rice fields, rainfed lowlands, tidal fields, and lowland swamps; (2) conduct socialization through demonstration plots; (3) increasing human resources through intensive training and counseling, especially in target areas; (4) providing capital assistance; (5) increasing the technology innovation supporting Tabela such as; a) superior varieties with high yield potential, b) fertilization, biodecomposers, biological fertilizers, c) control of plant pest organisms especially in the early growth/germination phase. Weed control either manually, or by selective use of pre-growth and post-growth herbicides, d) water management, and e) planting tool innovation.

\section{Conclusion}

Direct seed planting rice cultivation (Tabela) Jajar Legowo is one of the solutions for lowland rice farming that can solve the problem of labor shortages in the production process of rice cultivation. The technology of direct seed planting rice cultivation (Tabela) has developed, Tabela sebar, Tabela tegel, Tabela array and Tabela Jajar Legowo.

Supporting technology in Tabela rice cultivation is quite available including superior varieties, quality seeds, biological fertilizers, fertilization, weed control, water management, pest and disease control, and planting tools. Tabela technology has the prospect to be widely developed in Indonesia because its suitable for irrigated and rain fed rice fields, harvest faster, increases production, is more labor efficient, easy and practical to implement.

\section{References}

1. S.K. De Datta, Procedings $12^{\text {th }}$ Asian-Pacific Weed Science Society Conference, 2126 August 1989, Seoul, South Korea (1989) 
2. H. Supriadi, A. H. Malian, Prosiding Simposium III. Kinerja Penelitian Tanaman Pangan. Puslitbang Tanaman Pangan, Bogor (1993)

3. Z. Zulkifli, B. Rayco, D. Wurjandari, Growing Rice, Cultivating Partnership. 40 Years of Indonesia-IRRI Collaboration. Indonesia Center for Food Crop Research and Development. Indonesia Agency for Agricultural Research and Development. Ministry of Agriculture, Jakarta (2014)

4. Sahardi, Kartika, Idaryani, Repelita, A. Wahid, Kajian potensi dan peluang pengembangan teknologi spesifik lokasi budidaya padi tanam benih langsung di Sulawesi Selatan. Laporan Kegiatan BPTP Sulawesi Selatan, Indonesia (2017)

5. M.O. Adnyana, Pengkajian sistem usahatani berbasis padi dengan wawasan agribisnis (SUTPA) tahun 1995/1996. Pusat Penelitian Sosial Ekonomi Pertanian dan Pusat Penelitian dan Pengembangan Tanaman Pangan, Bogor, Indonesia (1997)

6. M. Azmi, D. E. Johnson, J. Trop. Agric. Food Sci. (2009)

7. A. Jamil, S. Abdurrahman, P. Sasmita, Z. Zarni, Wiratno, R. Rachmat, R. Saraswati, L. R. Widowati, E. Pratiwi, Satoto, Rahmini, D. Handoko, L. M. Zarwazi, M. Y. Samanullah, A. M. Yusuf, A. D. Subagio, Petunjuk teknis budidaya padi jajar legowo super. Balitbangtan Kementerian Pertanian, Jakarta, Indonesia (2016)

8. N. Razak, Sahardi, Buletin Inovasi dan Informasi Pertanian. BPTP Sulawesi Selatan. 1, 2 (2006)

9. Balitbangtan, Panduan teknologi budidaya padi tanam benih langsung. (Kementerian Pertanian, Jakarta, Indonesia, 2013)

10. A. Imran, Suryani, Sahardi, Jurnal Penelitian dan Pengembangan Teknologi Pertaniaan, 9, 2 (2006)

11. P. Bangun, H. Siregar, Jurnal Penelitian Pertanian Tanaman Pangan 20, 2 (2001)

12. H. Pane, Jurnal Litbang Pertanian, 22, 4 (2003)

13. N. Razak, Sahardi, M. P. Sirapak, Jurnal STIGMA, 13, 4 (2005a)

14. Sahardi, Metode cepat evaluasi varietas unggul baru padi toleran genangan pada fase perkecambahan. Laporan Hasil Penelitian BPTP Sulawesi Selatan, Indonesia, (2017)

15. Arafah, M. I. Ardah, Bunga Rampai Teknologi. BPTP Sulawesi Selatan, Indonesia (2017)

16. N. Razak, M.P. Sirapak, Sahardi, Prosiding Seminar Nasional Inovasi Teknologi Pertanian Berwawasan Agribisnis Mendukung Pembangunan Pertanian Wilayah Kepulauan. Puslitbang Sosek Pertanian, (2005b)

17. Sahardi, S. D. Iswari, Prosiding Ekspose dan Seminar Nasional; Inovasi Pertanian Ramah Lingkungan, (2013)

18. Herniwati, Sahardi, Prosiding Seminar Nasional Balai Besar Pengkajian dan Pengembangan Teknologi Pertanian, (BBP2TP Bogor, Indonesia 2011)

19. Idaryani, Sahardi, Keragaan pertumbuhan dan produksi varietas Inpari 7 di Sulawesi Selatan. Laporan Hasil Penelitian BPTP Sulawesi Selatan, Indonesia, (2015)

20. R. A. Reano, Proceeding Rice Seed Health Training Centre, IRRI Conference. July August 31, 2001, (Los Banos, Philippines, 2001)

21. N. Shenoy, T. Saudhya, R. Paris, B. Duff, Proceeding Network Orientation and Planning Workshop, IRRI, 2-11 May 2011, (Los Banos, Lagua, Philippines,1988)

22. M.P. Sirapak, N. Razak, Sahardi, Buletin. Budidaya Pertanian. Fakultas Pertanian Universitas Pattimura, 8, 2 (2012)

23. Sahardi, Jurnal Titian Agronomi, 3 (1991)

24. Herniwati, Sahardi, F. Djufry, Jurnal Informatika Pertanian, 23, 2 (2014) 
25. Sahardi, Herniwati, K. Fauziah, Prosiding Seminar Nasional: Peran inovasi dan kemitraan dalam mendukung program sentuh tanah di Sulawesi Utara, (2012)

26. Sahardi, J. Limbongan, Prosiding Seminar Nasional Penelitian Padi. Inovasi Teknologi Padi Mengantisipasi Cekaman Lingkungan Biotik dan Abiotik, Badan Litbang Pertanian, (2012)

27. Karlin, Sahardi, Jurnal AGRIVIGOR, 6, 2 (2007)

28. Sahardi, Jurnal Penelitian Gulma. Komisariat Indonesia Bagian Timur, (1989)

29. Sahardi, Jurnal Penelitian Sistem Usahatani, 2 (1995)

30. Arafah, N. Razak, Sahardi, Jurnal AGRIVIGOR, 4, 3 (2005)

31. Salimin, Dinamika Jurnal Ilmiah Teknik Mesin 2012, 3, 2 (2012)

32. Abidin, Z, Suharno, Sahardi, Jurnal STIGMA, 12, 1 (2004)

33. BBSDLP, Sumberdaya lahan pertanian Indonesia: luas, sebaran dan potensi ketersediannya. (Balitbangtan Kementerian Pertanian, Jakarta, Indonesia, 2016)

34. BPS, Statistik Indonesia. (Badan Pusat Statistik, Jakarta, Indonesia, 2017)

35. F. Djufri, Sahardi, A.B.I. Lompengeng, Integrasi padi-ternak dalam perspektif bioindustri di Sulawesi Selatan. Perspektif Pengembangan Model Pertanian Bioindustri. IAARD Press, (Badan Litbang Pertanian, Jakarta, 2015) 